\title{
Lightweight concrete with copper slag waste as sand substitution
}

\author{
Roman Jaskulski ${ }^{1}{ }^{*}$, and Wojciech Kubissa ${ }^{1}$ \\ ${ }^{1}$ Faculty of Civil Engineering, Mechanics and Petrochemistry, Warsaw University of Technology, \\ ul. Lukasiewicza 17, 09-400 Płock, Poland
}

\begin{abstract}
The paper presents results of tests of lightweight concrete made with copper slag waste material as fine aggregate (fraction $0-2 \mathrm{~mm}$ ) and two types of light aggregate (fractions $>2 \mathrm{~mm}$ ). Six series of concrete with three w/c ratios $(0.50,0.55$ and 0.60$)$ and two variants of cement content $\left(200 \mathrm{~kg} / \mathrm{m}^{3}\right.$ and $\left.300 \mathrm{~kg} / \mathrm{m}^{3}\right)$ were manufactured. Reference concretes were also prepared in which copper slag waste was replaced by the same mass of river sand. To maintain similar densities of mixtures with copper slag in comparison to those with sand mutual proportions of both lightweight aggregates were modified. On concrete specimens compressive strength was tested as well as the open porosity was determined by drying to stable mass at $65^{\circ} \mathrm{C}$. The concrete bulk density in saturated and dried state was also determined using hydrostatic weighing. The obtained results were compared with the results of the reference concrete tests. Results have shown that replacing sand with copper slag waste in lightweight concrete does not negatively affect their strength but may slightly increase their porosity.
\end{abstract}

\section{Introduction}

Recycling of waste materials became necessary. In recent years much attention is paid, beside reduction of $\mathrm{CO}_{2}$ emission, to rational management of waste. This is caused by necessity of the transition to an energy-efficient economy with frugal natural resources management policy, which became one of the main priorities of the EU 2020 strategy [1,2]. Cement and concrete industry try to fit in with the strategy and manufacturing of concrete with limited amount of cement clinker substituted by other binding materials and with waste components becomes one of the most important directions of development of concrete technology $[3,4,5]$. It should be emphasized, however, that simultaneously with these priorities, the demands on durability of concrete structures during its whole life cycle are increasing and impact of construction on the environment is becoming increasingly important [6].

The use of copper slag waste in the production of concrete can be a part of the sustainable development strategy. Copper slag is a by-product, produced besides mill tailing, during the process of copper extraction by smelting. Its physical properties are similar to natural sand [7] and some potential applications which have been described already [8,9]. The source of the waste is the surface blast-cleaning process in which copper slag is used as an abradant.

\footnotetext{
*Corresponding author: Roman.Jaskulski@pw.edu.pl
} 
After the cleaning process the material is considered as waste because its gradation becomes too fine to use it again for the same purpose. The content of $0-0.125 \mathrm{~mm}$ and $0.125-0.25$ $\mathrm{mm}$ fractions is significantly increased compared to river quartz sand. The waste also contains a small amount of corrosion products and corrosion protection coatings 10. Huge amount of its annual production is still disposed in landfills or stockpiles.

One of the most promising potential application for using original copper slag waste is concrete production $[11,12,13]$. It is possible to manufacture high-quality concrete, improving its properties compared to concrete with sand $[14,15]$. It has been found that copper slag used as sand substitution significantly improves consistency and compressive strength of concrete without changing the amount of mixing water [12,16]. It is also possible to retain the same consistency of the concrete mixture and reduce the amount of water by $22 \%$ with the significant compressive strength increase. It is very likely that copper slag waste, despite its higher fineness and some content of impurities, will also work well in the same applications. However it can affect workability of the concrete mixtures in a different way than original copper slag.

One of the fastest growing areas of concrete technology, which also allows to achieve a positive impact on the environment, are lightweight concretes, especially those made with the use of lightweight aggregates produced from waste materials (granules of recycled glass, fly ash and adjustment components, waste from sewage treatment plants and other).

The use of lightweight concrete can be traced to as early as 3000 B.C. when the towns of Mohenjo - Daro and Harappa in Pakistan were built with porous clay bricks. Later the Greeks and Romans used pumice when building their constructions, which some of them still exist like St. Sofia Cathedral (Hagia Sofia) in Istanbul and the Roman temple, the Pantheon and the Colosseum in Rome [17]. LWA (ie. expanded clay aggregate) was first manufactured from clay and shale sintered in a rotary kiln in 1917. Lightweight aggregate concrete (LWC) has been increasingly applied in high buildings (Shard London Bridge, Commerzbank in Frankfurt) and long-span bridges (Great Belt Bridge, Øresund Bridge, Wabash River Bridge, repairs of Tower Bridge), Concrete Offshore Platforms (Heidrun Floating Concrete Offshore Platform, CIDS Island Drilling System) and other applications [18].

LWC has many virtues. Mainly due to its $20-30 \%$ lower self-weight in comparison to normal weight concrete. It usually considered as an average- and low-strength material used mainly for subsidiary or non-bearing construction elements, but it is possible to manufacture lightweight concrete of high compressive strength [19]. The impact of high temperature on the strength of the lightweight concrete with aggregates fully saturated with water showed strength losses that were comparable to those observed in the concrete with standard aggregate 20. Another advantage of the material is wide use of waste materials in the production of lightweight aggregates $[21,22,23]$ including hazardous waste which is difficult to dispose of in any other way, such as petroleum soaked absorbents [24] or industrial waste containing heavy metals [25]. Therefore, there is every reason to believe that LWC has strong market competitiveness and it will be widely used for the civil engineering structure in the near future [26].

The aim of this work is to compare selected mechanical and structural properties of LWC manufactured with two kinds of different fractions of lightweight aggregate (Certyd and expanded clay aggregate) and copper slag waste as sand substitution. Received results of compressive strength, bulk density and open porosity were compared with values obtained for LWC manufactured with using similar recipes and lightweight aggregate but with sand replacing copper slag waste. Due to the difference in density of sand and copper slag, in order to obtain concretes of similar density, the same mass share of both fine aggregates and different mutual proportions of light aggregates in mixtures were assumed. also the amount of additional water due to the difference in absorbability of both light aggregates has been corrected. 


\section{Materials and methods}

\subsection{Materials and mix compositions}

Two lightweight aggregates as coarse aggregate were used to make lightweight concrete. The first, with a grain size of $4-8 \mathrm{~mm}$, is an aggregate under the trade name Certyd produced in the process of high-temperature sintering of ash from the combustion of coal in fine coal industrial boilers [27]. The other, with grain size $8-16 \mathrm{~mm}$, was expanded clay aggregate keramzite. Both of the lightweight aggregates used are presented in the illustrative form in Fig. 1.

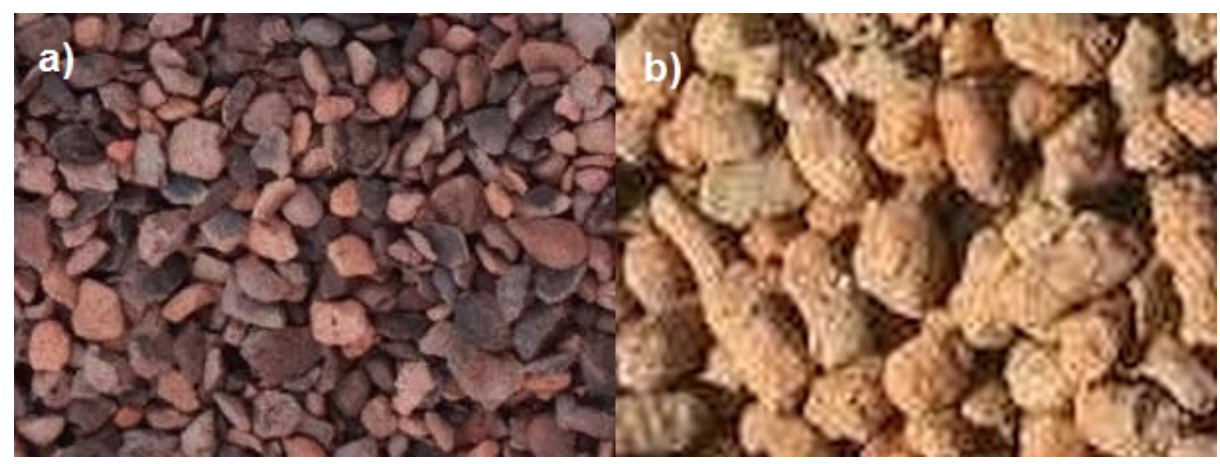

Fig. 1. Lightweight aggregate utilized in the tested concrete mixtures: a) Certyd, b) keramzite [28].

As fine aggregate, alternatively river quartz sand and copper slag waste were used. The second is shown in Fig. 2.

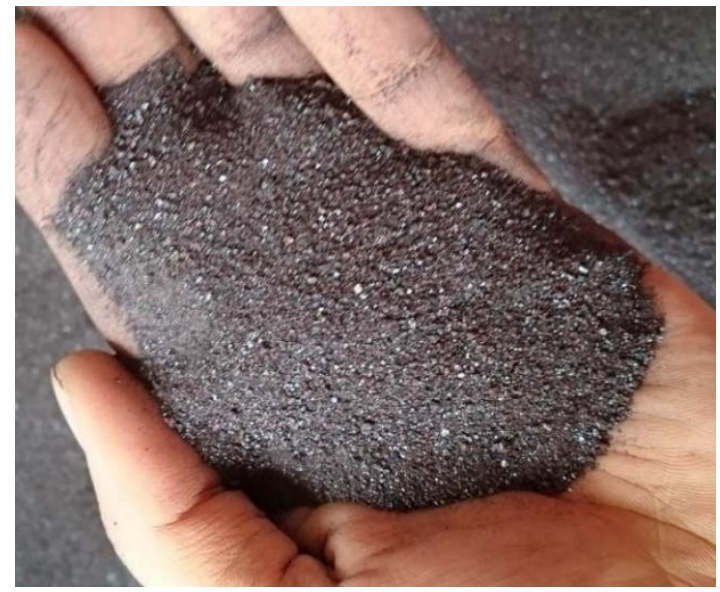

Fig. 2. Copper slag waste [28].

Portland-composite cement CEM II/B-M (V-LL) $32.5 \mathrm{R}$ was used as a binder and the ordinary tap water as mix water. Total of twelve concrete mixture compositions were designed. Six of them were manufactured with quartz river sand as a fine aggregate and six more with copper slag waste as the sand substitution. The concrete mixtures with the same kind of fine aggregate were additionally varied by assuming different values of w/c ratio $(0.50,0.55,0.60)$ as well as different cement content: $200 \mathrm{~kg} / \mathrm{m}^{3}$ and $300 \mathrm{~kg} / \mathrm{m}^{3}$.

In order to take into account the lightweight aggregate absorbability on the effective value of the w/c ratio of the concrete mixtures [29], the aggregate water absorption capacity was 
determined. The amount of water absorbed by the aggregate during 24 hours was respectively: $16.2 \%$ by mass in the case of Certyd aggregate and $21.6 \%$ in the case of keramzite. In the mix design, additional water was included in the amount of $80 \%$ of the water absorption capacity of both lightweight aggregates.

Two assumptions were made in concrete mixtures design. First, the mass fraction of fine aggregate in the corresponding mixtures with sand and copper slag waste was to be approximately the same. Second, bulk density of the hardened concrete was to be similar. Due to higher bulk density of copper slag waste in comparison to sand (approx. $2.99 \mathrm{~g} / \mathrm{cm}^{3}$ according to own tests) it was necessary to correct the mutual proportions of coarse lightweight aggregates, which also differed in bulk density (according to own tests: Certyd $1.75 \mathrm{~g} / \mathrm{cm}^{3}$ and keramzite $-1.27 \mathrm{~g} / \mathrm{cm}^{3}$ ). As a result in the mixtures with sand the mutual proportions of lightweight aggregates were $40 \%$ of Certyd and $60 \%$ of keramzite, and in case of the mixtures with copper slag waste there were $30 \%$ of Certyd and $70 \%$ of keramzite. Concrete mix proportion based on the above described assumptions are presented in Table 1.

Table 1. Concrete mix proportions.

\begin{tabular}{|c|c|c|c|c|c|c|c|}
\hline \multirow[b]{2}{*}{$\begin{array}{c}\text { Mix } \\
\text { designation }\end{array}$} & \multicolumn{6}{|c|}{ Component $\left[\mathrm{kg} / \mathrm{m}^{3}\right]$} & \multirow[b]{2}{*}{$\begin{array}{l}\text { w/c } \\
\text { ratio }\end{array}$} \\
\hline & Cement & Water & $\begin{array}{r}\text { River } \\
\text { sand }\end{array}$ & $\begin{array}{c}\text { Copper } \\
\text { slag } \\
\text { waste }\end{array}$ & Certyd & Keramzite & \\
\hline LCs-2/50 & 200 & 230 & 664 & --- & 409 & 446 & \multirow{4}{*}{0.50} \\
\hline $\mathrm{LCc}-2 / 50$ & 200 & 236 & --- & 662 & 322 & 546 & \\
\hline LCs-3/50 & 300 & 267 & 599 & --- & 369 & 402 & \\
\hline $\mathrm{LCc}-3 / 50$ & 300 & 272 & --- & 597 & 291 & 492 & \\
\hline LCs-2/55 & 200 & 238 & 656 & --- & 404 & 440 & \multirow{4}{*}{0.55} \\
\hline $\mathrm{LCc}-2 / 55$ & 200 & 244 & --- & 654 & 319 & 539 & \\
\hline LCs-3/55 & 300 & 280 & 587 & --- & 362 & 394 & \\
\hline $\mathrm{LCc}-3 / 55$ & 300 & 285 & --- & 585 & 285 & 482 & \\
\hline LCs-2/60 & 200 & 247 & 648 & --- & 400 & 435 & \multirow{4}{*}{0.60} \\
\hline $\mathrm{LCc}-2 / 60$ & 200 & 252 & --- & 646 & 315 & 533 & \\
\hline LCs-3/60 & 300 & 293 & 575 & --- & 354 & 386 & \\
\hline LCc-3/60 & 300 & 297 & --- & 573 & 279 & 473 & \\
\hline
\end{tabular}

\subsection{Specimens preparation}

The concrete mixtures were prepared in a forced action laboratory mixer. First the dry components were mixed and then water was added in two portions. Concrete specimens were formed in plastic moulds in two layers. Each of the layers was compacted on vibration table. The specimens were demoulded after two days and were put into water containers until the testing but not shorter than the concrete reached the age of 28 days.

Two kinds of specimens were prepared. For compressive strength test $100 \mathrm{~mm}$ cube specimens, while to measure the bulk density and open porosity $150 \times 300 \mathrm{~mm}$ cylinders were casted, which were subsequently cut into approximately $25 \mathrm{~mm}$ thick discs on which the measurements were performed. 


\subsection{Performed tests}

\subsubsection{Compressive strength test}

Compressive strength was tested on $100 \mathrm{~mm}$ cubic specimens 28 days after casting. Until the test the specimens were stored in a container with water in laboratory. To perform the test compression machine Toni Technik ToniPACT II with $3000 \mathrm{kN}$ capacity was used.

The test procedure was performed in accordance with PN-EN 12390-3. The rate of loading was set at $0.5 \mathrm{MPa} / \mathrm{s}$. For each concrete series eight specimens were tested. The results were statistically analysed in order to find possible outliers and then averaged. Besides the mean value the measurement uncertainty was also calculated with use of $t$ Student distribution.

\subsubsection{Bulk density and open porosity determination}

Bulk density was determined on specimens in two conditions: fully saturated with water and oven dried in $65^{\circ} \mathrm{C}$ to stable mass. The procedure consisted of three weighing. Two of them were performed on saturated specimens and the third on dried ones. First the specimens saturated mass $m_{\mathrm{s}}$ was determined. Then the hydrostatic weighing was performed and the mass of the specimen submerged in water $m_{\mathrm{w}}$ was determined. The last, but not least, mass $m_{\mathrm{d}}$ was determined after specimens drying.

Bulk density $\rho_{\mathrm{s}}$ of saturated hardened concrete mixtures was calculated using Eq (1).

$$
\rho_{\mathrm{s}}=m_{\mathrm{s}} /\left(m_{\mathrm{s}-} m_{\mathrm{w}}\right)
$$

For calculations of density $\rho_{\mathrm{d}}$ of dried hardened concrete mixtures Eq. (2) was used

$$
\rho_{\mathrm{d}}=m_{\mathrm{d}} /\left(m_{\mathrm{s}-} m_{\mathrm{w}}\right)
$$

and the open porosity $p$ was calculated using Eq. (3)

$$
p=\left(m_{\mathrm{s}-} m_{\mathrm{d}}\right) /\left(m_{\mathrm{s}-} m_{\mathrm{w}}\right)
$$

For each concrete series nine specimens were tested. The results were, as in case of compressive strength, statistically analysed in order to find possible outliers and then averaged. Besides the mean value the measurement uncertainty was also calculated with use of $\mathrm{t}$ Student distribution.

\section{Results and conclusions}

\subsection{Compressive strength}

Results of compressive strength test are presented on Fig. 3. For better illustration of the results of similar concrete series differing in fine aggregate type (sand or copper slag waste) they were arranged next to each other and described by one common mixture designation.

The highest compressive strength was obtained for LC-3/50 with sand and the lowest for LC-2/50 with sand. Analysing the results some more observations can be easily made. First of all it should be mentioned, that only in case of one concrete mixture (LC-3/50) the results differ more from each other than the measurement uncertainty. For this mixture the higher compressive strength is observed for series with sand as fine aggregate. If the mean values are analysed, without taking into account the measurement uncertainty, than we can see some 
another interesting trend. Increasing w/c ratio changes the differences in compressive strength between similar series in favour of those with copper slag waste. However for mixtures with $300 \mathrm{~kg} / \mathrm{m}^{3}$ the compressive strength is higher for series with sand, in the contrary to mixtures with $200 \mathrm{~kg} / \mathrm{m}^{3}$ of cement.

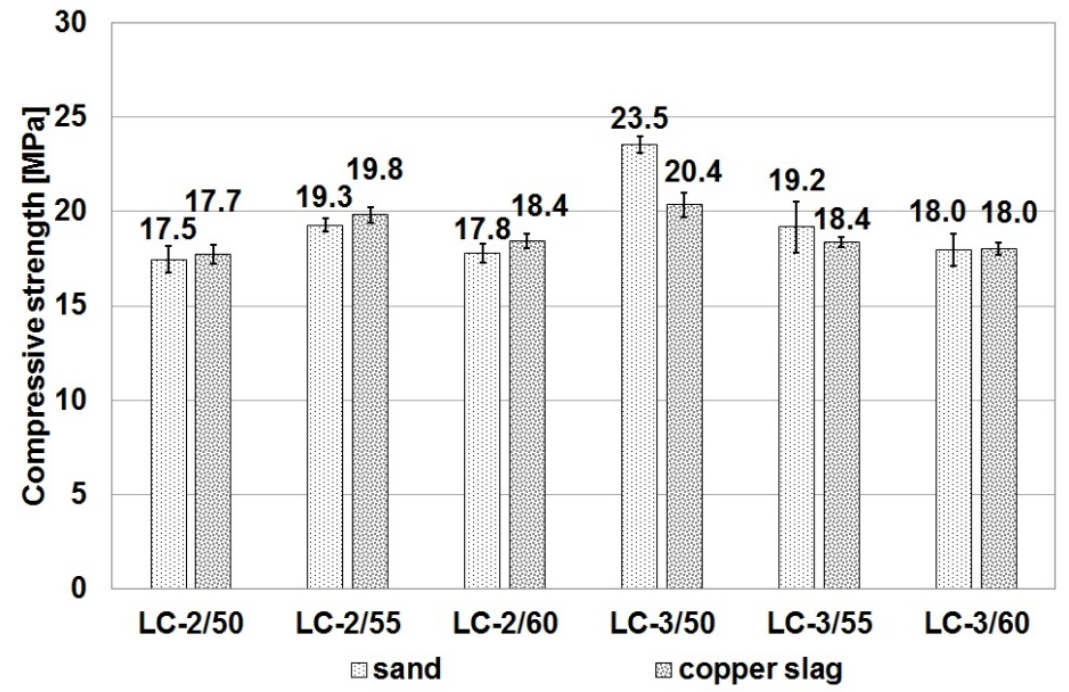

Fig. 3. Compressive strength test results.

\subsection{Bulk density and open porosity}

Results of bulk density determination are shown in Tab. 2. Obtained values of bulk density vary from $1.76 \mathrm{~g} / \mathrm{cm}^{3}$ to $1.88 \mathrm{~g} / \mathrm{cm}^{3}$ for saturated specimens and from $1.53 \mathrm{~g} / \mathrm{cm}^{3}$ to $1.63 \mathrm{~g} / \mathrm{cm}^{3}$ for dried specimens. In most cases bulk density of concrete series with copper slag waste are higher than of the series with sand, but the differences between determined values are not higher than $3 \%$. This means that the initial assumption for achieving a similar density of the concrete mixes has been met.

Table 2. Values of bulk density.

\begin{tabular}{|l|c|c|c|c|c|c|}
\hline \multicolumn{1}{|c|}{ Mixture } & LC-2/50 & LC-2/55 & LC-2/60 & LC-3/50 & LC-3/55 & LC-3/60 \\
\hline \multicolumn{7}{|c|}{ Bulk density determined on saturated specimens [g/cm $\left.{ }^{3}\right]$} \\
\hline with sand & $1.76 \pm 0.01$ & $1.80 \pm 0.02$ & $1.82 \pm 0.01$ & $1.84 \pm 0.01$ & $1.84 \pm 0.01$ & $1.83 \pm 0.05$ \\
\hline with copper slag & $1.77 \pm 0.04$ & $1.83 \pm 0.02$ & $1.88 \pm 0.01$ & $1.83 \pm 0.04$ & $1.88 \pm 0.02$ & $1.87 \pm 0.03$ \\
\hline \multicolumn{7}{|c|}{ Bulk density determined on dried specimens [g/cm $\left.{ }^{3}\right]$} \\
\hline with sand & $1.55 \pm 0.01$ & $1.58 \pm 0.02$ & $1.59 \pm 0.01$ & $1.59 \pm 0.02$ & $1.58 \pm 0.01$ & $1.54 \pm 0.06$ \\
\hline with copper slag & $1.53 \pm 0.05$ & $1.60 \pm 0.02$ & $1.63 \pm 0.01$ & $1.59 \pm 0.04$ & $1.60 \pm 0.02$ & $1.58 \pm 0.03$ \\
\hline
\end{tabular}

Open porosity determination results are presented on Fig. 4. They are arranged in the same way as the compressive strength results. As it can be seen the porosity increases with increasing value of $\mathrm{w} / \mathrm{c}$ ratio. What is more, the porosity is higher for mixtures with higher cement content. It strongly suggests that the porosity of cement matrix is higher than the porosity of lightweight aggregate. In addition, in all cases the porosity of the copper slag waste concrete series is higher than the porosity of the series with sand. This is probably the effect of higher content of lightweight aggregate and its different proportions (higher content 
of more porous aggregate). In most cases, however, the differences are not statistically significant.

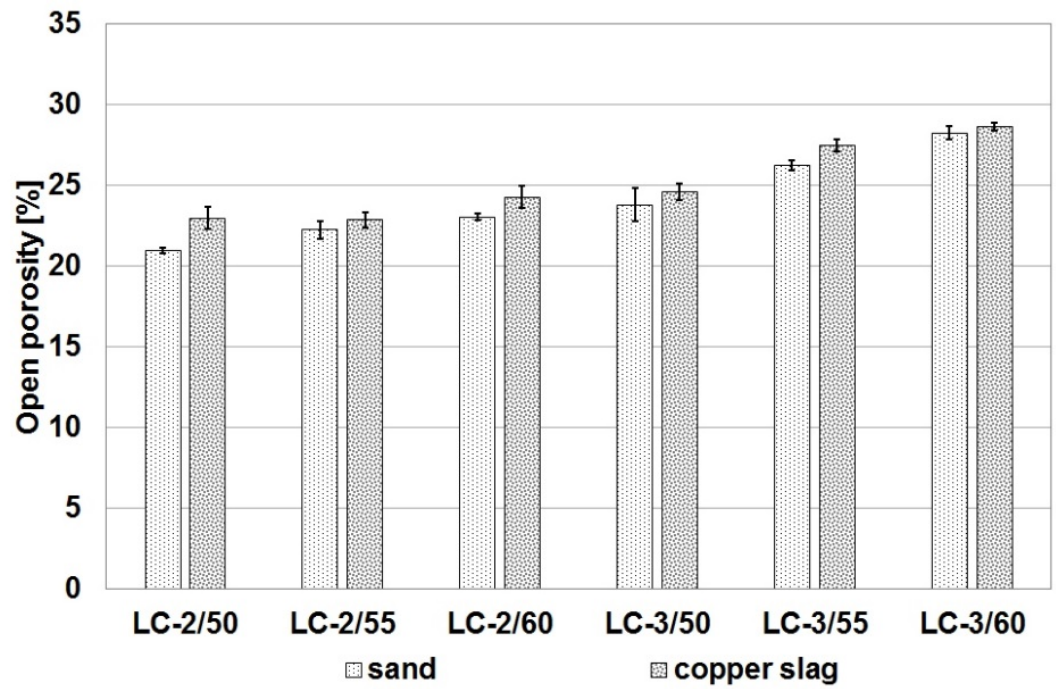

Fig. 4. Open porosity determination results.

\subsection{Summary and conclusions}

The obtained results indicate that it is possible to produce lightweight concrete with aggregate heavier than sand (copper slag waste) with similar density and without significant deterioration of mechanical properties. The resultant compressive strength of concrete with copper slag waste in range from 17.7 MPa to $20.4 \mathrm{MPa}$ is sufficient in most applications of lightweight concrete. And in most cases of tested concrete mixtures the results of strength test are not significantly different from strength of concrete mixtures with sand.

The resultant higher porosity of the concrete produced with copper slag waste can be an advantage in many applications, because higher porosity is likely to result in a lower thermal conductivity. It may be important if such a material is used in external wall of buildings. The differences in porosity varies from $1.3 \%$ in case of LC-3/60 concrete mixture to $9.7 \%$ in case of LC-2/50 concrete mixture.

In the face of depletion of stocks of natural resources, the more often use of waste materials such as of copper slag waste is necessary and it would be a good news if it was used more often in manufacturing of lightweight concretes.

It seems advisable to continue research on lightweight concrete with copper slag waste to determine the thermal properties of the material, as well as other mechanical properties (eg. tensile strength, modulus of elasticity) and also some durability properties (eg. sorptivity, frost resistance, etc.).

Authors wish to thank Artur Sieciński for his help in preparing specimens and carrying out tests.

\section{References}

1. E. Holden, K. Linnerud, and D. Banister (2016)

2. I. Broman, K. Rob, J. Clean. Prod. J. 140, 17-31 (2015)

3. L. Czarnecki, W. Kurdowski, Technol. Archit. 37, 50-55 (2007) 
4. M.A. Glinicki, Przegląd Bud. 12, 24-30 (2007)

5. S. Bentur, A. Katz, S. Mindess, Cem. Wapno Beton 11, 73, 102-121 (2006)

6. A. Ajdukiewicz, Przegląd Bud. 2, 20-29 (2011)

7. S. Meenakshi Sudarvizhi, R. Ilangovan, Int. J. Civ. Struct. Eng. 1(4), 918-927 (2011)

8. B. Gorai, R.K. Jana, Premchand, Resour. Conserv. Recycl. 39(4), 299-313 (2003)

9. R.K. Dhir, J. de Brito, R. Mangabhai, C.Q. Lye, Sustainable Construction MaterialsCopper Slag (Woodhead Publishing, Cambridge, 2017)

10. J. Rzechuła, Fizykochem. Probl. Miner. Zesz. 28207-218, A. Łuszczkiewicz, Ed., (Politechnika Wrocławska, Wrocław, 1994)

11. T. Ayano, K. Sakata, Spec. Publ. 192, 141-158 (2000)

12. K.S. Al-Jabri, A.H. Al-Saidy, R. Taha, Constr. Build. Mater. 25(2), 933-938 (2011)

13. I. Alp, H. Deveci, H. Süngün, J. Hazard. Mater. 159(2-3), 390-395 (2008)

14. K.S. Al-jabri, M. Hisada, A.H. Al-saidy, S.K. Al-oraimi, Constr. Build. Mater. 23, 2132-2140 (2009)

15. P.S. Ambily, C. Umarani, K. Ravisankar, P. Ranjan, B.H. Bharatkumar, N.R. Iyer, Constr. Build. Mater. 77, 233-240 (Elsevier Ltd, 2015)

16. W. Wu, W. Zhang, G. Ma, Mater. Des. 31, 6, 2878-2883 (2010)

17. S. Chandra, L. Berntsson, Light. Aggreg. Concr. (2002)

18. L. Domagała, Przegląd Bud. 9, 38-44 (2016)

19. L. Domagała, M. Urban, Przegląd Bud. 4/2004, 35-39 (2004)

20. L. Domagała, I. Hager, Cem. Wapno Beton 17(3), 138-143 (2012)

21. A. Mueller, S. N. Sokolova, V. I. Vereshagin, Constr. Build. Mater. (2008)

22. C.L. Hwang, L.A.T. Bui, K.L. Lin, C.T. Lo, Cem. Concr. Compos. (2012)

23. L. Domagała, K. Kurzyniec, Energy Effic. Sustain. Build. Mater. Prod., 303-313 (2017)

24. W. Franus, G. Jozefaciuk, L. Bandura, M. Franus, Minerals (2017)

25. B. Gonzalez Corrochano, J. Alonso Azcarate, M. Rodas Gonzalez, B.G. Corrochano, M.R. Gonzalez, Int. J. Environ. Sci. Technol. (2011)

26. Y. Gao, L. Cheng, Z. Gao, S. Guo, Constr. Build. Mater. (2013)

27. K. Łuczaj, P. Urbańska, Mater. Bud. 1(12), 44-47 (2015)

28. A. Sieciński, Badanie wybranych właściwości cieplnych betonu na kruszywie lekkim, (Politechnika Warszawska, 2017)

29. L. Domagała, Procedia Eng. 108, 206-213 (2015) 